\title{
Readiness of Adults to Learn Using E-learning, M-learning and T-learning Technologies
}

\author{
Rytis VILKONIS, Tatjana BAKANOVIENĖ, Sigita TURSKIENE் \\ Šiauliai University, Distance Study Centre \\ Vasario 16 st. 26, LT-76352, Šiauliai, Lithuania \\ e-mail: rytis.v@distance.su.lt,atani78@yahoo.com, sigita.t@distance.su.lt
}

Received: January 2013

\begin{abstract}
The article presents results of the empirical research revealing readiness of adults to participate in the lifelong learning process using e-learning, m-learning and t-learning technologies. The research has been carried out in the framework of the international project eBig3 aiming at development a new distance learning platform blending virtual learning environments, television and mobile technologies. Readiness to learn in a distance mode using e-learning, m-learning and t-learning technologies has been analysed on the ground of self-assessment of adults' computer literacy, usage of e-services including e-learning in a distance mode, experience in and attitude towards the choice of the mode of learning.
\end{abstract}

Keywords: life long learning, e-learning, m-learning, t-learning.

\section{Introduction}

Increasingly more adults get involved into the process of lifelong learning on their own initiative. The demand for non-formal education also increases with regard to learning without leaving the place of residence, not interrupting work performance, family life. Open, distance learning using virtual learning environments (VLE) provides conditions for implementation of this demand of the society. The idea of open learning is not new. Open learning is understood, first of all, as freedom of learners to raise learning aims and choose the ways to implement them (Wedemeyer, Charles, 1973). As A. Valiukevičiūtè (2005) holds it, the aim of development of distance learning possibilities is not so much about modernisation of educational processes, but rather implementation of the idea of openness of learning. Openness of learning is the base of distance learning. This is the opportunity to set a teacher and a student free from limitations of time and space. In distance studies, the character of studying changes: they become more individualised, a teacher becomes an advisor and leader (Rutkauskienè, 2003). Perfection of e-learning technologies creates new possibilities for distance learning and openness of learning. Numerous definitions on e-learning can be found, however, having drawn generalisations on them, it can be stated that essentially e-learning is the learning based on information and communication technologies (ICT), as I. Šileikienè (2004, p. 4) puts, "aiming at its 
quality and efficiency, $<\ldots>$ partially transferred to the virtual space”. A. Targamadzè and R. Petrauskienè (2008) characterise e-learning as face-to-face learning which, aiming at its quality and efficiency, is enriched with the ICT means and the process of learning is usually transferred to the virtual space. Both distance and e-learning via the Internet and its services suggest participants of the process an opportunity to quickly update information, to search for information according to key words, to share accumulated information etc. The tendency is observed that due to e-learning technologies, face-to-face and distance learning are getting closer; thus, the increasing requirements for education and lifelong learning are met (Butkevičienè et al., 2008). However, perfection of distance learning by means of e-learning technologies requires appropriate technologies-related readiness of learners and independent, self-directed conceptions of learning. A. Kazlauskiene et al. (2011) state that competences of e-learning only now seem like an educational innovation, but in the future they will be necessary for target groups of various educational institutions.

Tendencies of distance learning and expression of necessary competences at various levels is being analysed in Lithuania in various aspects in different contexts. In the context of continuous vocational training, possibilities of application of distance learning have been investigated by M. Teresevičienè et al. (2008). As the authors maintain, development of the network of distance learning, participation of scientific and educational institutions in this process provide conditions for implementation of the principles of lifelong learning, to diminish the divide among various groups of inhabitants (rural and urban residents, people belonging to different groups etc.). The research carried out by R. Vilkonis and I. Barabanova (2010) revealed the experience of comprehensive school 9th-12th forms' pupils in independent learning by applying e-learning elements, the need for pedagogical support in independent learning. Unfortunately, not all educational institutions have the ability to take full advantages of the newest information technology (Misevičienè, Budnikas, Ambrazienè, 2011). The research by R. Vilkonis and S. Turskienè (2009) indicates that majority of centres for adult non-formal education are ready to start providing services of distance learning; nevertheless, during the research the lack of material-technical and human resources was observed.

Rapid development of ICT opens new ways for perfection of various educational processes, provides conditions for the change in transition from the teaching paradigm to the learning paradigm. New e-learning possibilities are facilitated by advancing mobile technologies (m-learning) and television (t-learning). J. Wishart (2009) states that personal digital assistants (PDAs), palmtops and smart phones can be used in the process of both formal and non-formal education. As the author states, exactly mobile technologies at present enable development of the ideas of open learning which provide pupils with the opportunity to reach instructional material at any time and in any place. A learner becomes a creator of one's learning process and its active participant. Cutting-edge possibilities of television encourage remembering the experience of usage of television for distance education accumulated in the second half of the $20^{\text {th }}$ century. The latter was characteristic of passiveness of learners. As Aarreniemi-Jokipelt (2005) puts, TV-learning, or t-learning, should be understood as interactive learning. According to the author, presently t-teaching and t-learning encompass the blend of two major technologies (a TV set and a computer) as well as additional usage of mobile phones and Internet connection. 
Involvement of these means provides teaching and learning with interaction and ensures active learners participation.

According to A.Kapenieks et al. (2012), the available e-learning devices are still limited: the mobile screen is too small for large pieces of text and diagrams; digital TV is not sufficiently interactive, and classical e-learning does not yet deliver any time, any place learning that technologically enhanced learning promises. On the other hand typical Life Long Learners watch TV every day and they are often dissatisfied with the available content of the LLL programmes. Typically, they have mobile phones that they use to deliver SMSs; but they fail to exploit the full learning potential of these gadgets for lack of an appropriate learning strategy and system. As a solution, Latvian and Lithuanian crossborder collaboration project eBig3 is presenting a new trend in eLearning development that builds on the concept e-ecosystems. It is based on the complementary integration of the three major technologies: internet, television and mobiles that refer to as the eBig3. The methodology of eBig3 approach is based on accessing the strengths and weaknesses of e-, t-, and m-technologies. In the following table (Table 1) the application of e-, t-, and $\mathrm{m}$-technologies applied to Life Long Learning. The technologies were evaluated in the relation on their applicability to: 1) ease of joining the course, 2) content delivery, 3) study support technology, 4) effective organization of face-to-face seminars, 5) course completion awarded by a certificate.

By integrating three types of ICTs: e-, t-, and m-technologies, the eBig3 learning approach delivers the advantages of all three (Table 2).

Readiness of learners to learn applying state-of-the-art e-learning technologies depends on many factors including learners' ability to use contemporary ICT and willingness (Teresevičienè et al., 2008). As the authors maintain, readiness of a learner is one of the

Table 1

Applicability of Internet e-learning, t-learning, and m-learning for an integrated Life Long Learning approach (A.Kapenieks et al., 2012)

\begin{tabular}{|c|c|c|c|}
\hline & Internet e-learning & t-learning & m-learning \\
\hline $\begin{array}{l}\text { Ease of joining the } \\
\text { course }\end{array}$ & $\begin{array}{l}\text { With university registrar or } \\
\text { through an open courseware } \\
\text { without registration }\end{array}$ & $\begin{array}{l}\text { No need to sign-up, just } \\
\text { watch us on TV learning } \\
\text { channels }\end{array}$ & $\begin{array}{l}\text { With university registrar or } \\
\text { through open courseware } \\
\text { without registration }\end{array}$ \\
\hline Content delivery & Over PC learning portal & Over TV channel & With a mobile device \\
\hline $\begin{array}{l}\text { Learning } \\
\text { conditions }\end{array}$ & $\begin{array}{l}\text { Individualized learning } \\
\text { with PC }\end{array}$ & $\begin{array}{l}\text { In relaxing settings among } \\
\text { other TV viewers }\end{array}$ & $\begin{array}{l}\text { Small screen with limited } \\
\text { navigation }\end{array}$ \\
\hline $\begin{array}{l}\text { Study support } \\
\text { availability }\end{array}$ & $\begin{array}{l}\text { Possible over internet, } \\
\text { but limited to when the } \\
\text { computer is in use; e-mail, } \\
\text { chat, skype }\end{array}$ & $\begin{array}{l}\text { Very limited on broadcast } \\
\text { TV; available only in the } \\
\text { case of interactive TV } \\
\text { systems }\end{array}$ & $\begin{array}{l}\text { Over the phone, but limited } \\
\text { by a voice and small screen }\end{array}$ \\
\hline $\begin{array}{l}\text { Face-to-face } \\
\text { seminars }\end{array}$ & $\begin{array}{l}2 \text { to } 3 \text { course seminars } \\
\text { when following a blended } \\
\text { learning approach }\end{array}$ & $\begin{array}{l}\text { No place for seminars for } \\
\text { TV watchers }\end{array}$ & $\begin{array}{l}\text { Limited amount of content } \\
\text { does bnot require face-to- } \\
\text { face seminars with mobile } \\
\text { device }\end{array}$ \\
\hline $\begin{array}{l}\text { Course completion } \\
\text { certificate }\end{array}$ & $\begin{array}{l}\text { For registered users } \\
\text { participating in face-to- } \\
\text { face seminars }\end{array}$ & $\begin{array}{l}\text { Not possible for TV } \\
\text { viewers }\end{array}$ & $\begin{array}{l}\text { Limited amount of content } \\
\text { insufficient certificate }\end{array}$ \\
\hline
\end{tabular}


Table 2

Applicability of eBig3 learning approach to Life Long Learning (A.Kapenieks et al., 2012)

\begin{tabular}{ll}
\hline & eBig3 \\
\hline How to join the course? & $\begin{array}{l}\text { Sending SMS to an assigned mobile phone number presented } \\
\text { eBig3 / ETM television component }\end{array}$ \\
Content delivery & Mainly over the Internet or provision of printed workbook \\
Study support applications & Mainly over the mobile telephone \\
Face-to-face seminars & Easy to organize for registered course participants \\
Course completion certificate & Easy to issue to registered course participants \\
\hline
\end{tabular}

main elements of the e-learning system the exceptionality of which is highly significant in development of e-learning networks at various levels. The research by V. Vaičiūnienė and F. Gedvilienè (2008) revealed a strongly positive interaction among information literacy, development of critical thinking and flexible Moodle environment.

Trying to connect e-, $\mathrm{t}$-, and $\mathrm{m}$-technologies in one eBig3 learning system is important to learn better target group, its ability and desire to learn using these new opportunities. This research is aimed at revelation of readiness of adults to learn using e-, t-, and mtechnologies.

\section{The Research Method}

Readiness of adults to learn using e-learning, m-learning and t-learning technologies has been analysed in three aspects:

a) technological (self-assessment in computer literacy),

b) attitudes towards the mode of learning and

c) experience in using other e-services.

A questionnaire-based survey was the main research method. The research data has been processes employing SPSS 13.0 software package, applying methods of descriptive statistics and a non-parametric Mann-Whitney $U$ criterion to assess statistical significance of difference (the difference was statistically significant when the value of the significance level $\alpha$ was $\mathrm{p}<0.05$ ) (Čekanavičius, Murauskas, 2000).

\section{Research Sample and Characteristics of Respondents}

The research has been carried out in the Northern Lithuania region in 2012. The research sample was formed by the non-stochastic selection of the group of the surveyed, on the ground of the volunteering principle and method of formation of target groups (Kardelis, 2002; Bitinas, 2006). The surveyed comprised employable residents of Lithuania in the region at the Lithuania- Latvia border. When carrying out the survey, it was regarded that the target group could comprise learning and not learning adults, working as hired staff or being unemployed. In total, 248 adults have been surveyed: 196 women (79 per cent) 
and 52 men ( 21 per cent). According to the age, the surveyed were distributed almost evenly ( 84 were up to $25 ; 58$ were at the age of $26-35,50$ were $36-45$, 54 were $46-55$ years old), except 56-year-olds and older ( 2 surveyed). In the aspect of education, those having university-level (92 surveyed) and secondary, special education ( 86 surveyed) dominated. Fewer were holding a non-university level education degree (56 surveyed). According to the social status, majority of the surveyed were employed at state or private enterprises (100 surveyed), the jobless (86) and students (78), 10 state or municipality office-holders.

\section{Research Results}

Self-assessment in computer literacy shows that majority of the surveyed obtained good basics of computer usage (Table 3 ).

One fifth of the surveyed participants poorly assess their computer literacy; this fact can limit their fluent involvement into both the lifelong learning process and labour market.

Self-assessment of the surveyed in the aspect of main abilities to use ICT is presented in Table 4.

When analysing the results of self-assessment of abilities to use ICT, we observe that the abilities to use e-services (e-banking, e-shops etc.) have been self-assessed the most favourably. This shows that possibilities provided by e-services are assessed positively,

Table 3

Results of self-assessment of adults' computer literacy

\begin{tabular}{lrr}
\hline Level of computer literacy & N & $\%$ \\
\hline Good, but without approval & 138 & 55.6 \\
Good, approved by the European Computer Driving Licence (ECDL) & 58 & 23.4 \\
Poor & 50 & 20.2 \\
No abilities to use a computer & 2 & 0.8 \\
\hline
\end{tabular}

Table 4

Self-assessment of abilities to use

\begin{tabular}{|c|c|c|c|c|c|c|c|c|}
\hline \multirow[t]{2}{*}{ Abilities } & \multicolumn{2}{|c|}{ Excellent } & \multicolumn{2}{|c|}{ Good } & \multicolumn{2}{|c|}{ Poor } & \multicolumn{2}{|c|}{ None } \\
\hline & $\mathrm{N}$ & $\%$ & $\mathrm{~N}$ & $\%$ & $\mathrm{~N}$ & $\%$ & $\mathrm{~N}$ & $\%$ \\
\hline $\begin{array}{l}\text { To use main Internet services (information search, e-mail, } \\
\text { social networks etc.) }\end{array}$ & 130 & 52,8 & 88 & 35.8 & 22 & 8.9 & - & - \\
\hline To use various e-services (e-banking, e-shops etc.) & 92 & 38.0 & 102 & 42.1 & 34 & 14.0 & 12 & 5.0 \\
\hline To prepare computer-facilitated textual and visual materials & 74 & 30.6 & 112 & 46.3 & 46 & 19.0 & 8 & 3.3 \\
\hline To prepare slides for reports, presentations & 72 & 29.8 & 106 & 43.8 & 52 & 21.5 & 8 & 3.3 \\
\hline To work with e-documents (laws, books, reports etc.) & 60 & 24.6 & 116 & 47.5 & 50 & 20.5 & 14 & 5.7 \\
\hline $\begin{array}{l}\text { To apply hardware and software in practice according to } \\
\text { the needs }\end{array}$ & 38 & 15.8 & 108 & 45.0 & 72 & 30.0 & 20 & 8.3 \\
\hline
\end{tabular}


their usage does not cause discomfort to users, does not require additional competences. Therefore, main principles of the model of provision of e-services (interactivity, dissemination of information, accessibility etc.) can be significant for development of distance learning networks and e-learning technologies.

The data of Table 5 suggests that a computer is usually used for the information search on the Internet, carrying out of job tasks and inter-communication. E-services are being more seldom used (Table 5). More than a half (67.5 per cent) of the surveyed pay taxes, purchase (57.7 per cent) or sell goods (41.3 per cent) via the Internet.

During the research it was aimed at finding out the attitude of the surveyed when choosing the forms of educational-information support in learning. The data has been statistically analysed in the context of self-assessment in computer literacy (Table 6). The statistical analysis shows which modes of educational-information support have been more often chosen by the adults who assess their computer literacy as "good".

The analysis of the research results allows stating that the ability of learners to use ICT is a significant factor in choosing the mode of learning. Persons who assessed their computer literacy as "good" more often chose modes of e-learning and m-learning; whereas persons who assessed their computer literacy as "poor" more often chose theoretical lectures in auditoria, blended lectures and practical classes in auditoria. The research results suggest that e-learning and m-learning possibilities and demand can change depending on the ability to use ICT. The research doesn't show relations between learners' ability to use ICT and t-learning.

Aiming at finding out readiness of adults to learn using e-learning technologies, experience in distance learning has been investigated too. It has been estimated that one third of the surveyed have gained experience in distance learning (Table 7). Majority of them obtained this kind of experience at institutions of higher education.

This was predetermined by a well-developed network of distance learning services in higher education. As it was mentioned in the introductory part, the system of non-formal

Table 5

Actions and frequencies of adults' using computers

\begin{tabular}{|c|c|c|c|c|c|c|c|c|c|c|}
\hline \multirow[t]{2}{*}{ Actions } & \multicolumn{2}{|c|}{ Every day } & \multicolumn{2}{|c|}{$\begin{array}{l}1-2 \text { times } \\
\text { per week }\end{array}$} & \multicolumn{2}{|c|}{$\begin{array}{l}1-2 \text { times } \\
\text { per month }\end{array}$} & \multicolumn{2}{|c|}{$\begin{array}{l}\text { Less than once } \\
\text { per month }\end{array}$} & \multicolumn{2}{|c|}{ Never } \\
\hline & $\mathrm{N}$ & $\%$ & $\mathrm{~N}$ & $\%$ & $\mathrm{~N}$ & $\%$ & $\mathrm{~N}$ & $\%$ & $\mathrm{~N}$ & $\%$ \\
\hline $\begin{array}{l}\text { Search for information on the } \\
\text { Internet }\end{array}$ & 166 & 66.9 & 44 & 17.7 & 10 & 4.0 & 14 & 5.6 & 12 & 4.8 \\
\hline Communication & 142 & 57.7 & 50 & 20.3 & 14 & 5.7 & 14 & 5.7 & 24 & 9.8 \\
\hline Performance of job tasks & 104 & 42.6 & 50 & 20.5 & 20 & 8.2 & 14 & 5.7 & 52 & 21.3 \\
\hline $\begin{array}{l}\text { Spending leisure time (watching } \\
\text { films, playing games) }\end{array}$ & 76 & 31.1 & 80 & 32.8 & 40 & 16.4 & 26 & 10.7 & 22 & 9.0 \\
\hline Payment of taxes & 4 & 1.6 & 16 & 6.5 & 124 & 50.4 & 22 & 8.9 & 80 & 32.5 \\
\hline Purchase via the Internet & 2 & 0.8 & 10 & 4.1 & 32 & 13.0 & 98 & 39.8 & 104 & 42.3 \\
\hline $\begin{array}{l}\text { Announcement of information } \\
\text { on goods for sale }\end{array}$ & - & - & 6 & 2.4 & 18 & 7.3 & 76 & 30.9 & 142 & 57.7 \\
\hline
\end{tabular}


Table 6

The choice of educational-information support modes in the context of computer literacy

\begin{tabular}{|c|c|c|c|c|c|}
\hline & $\begin{array}{l}\text { Computer } \\
\text { literacy }\end{array}$ & $\begin{array}{l}\text { Mean } \\
\text { Rank }\end{array}$ & $\begin{array}{l}\text { Sum of } \\
\text { Ranks }\end{array}$ & $\begin{array}{l}\text { Mann- } \\
\text { Whitney U }\end{array}$ & $\mathrm{p}$ \\
\hline \multirow[t]{2}{*}{ Theoretical lectures in auditoria } & Good & 126.60 & 24814.00 & \multirow[t]{2}{*}{3116.00} & \multirow[t]{2}{*}{$0.002 *$} \\
\hline & Poor & 93.32 & 4106.00 & & \\
\hline \multirow{2}{*}{$\begin{array}{l}\text { Blend of lectures and practical } \\
\text { classes in auditoria }\end{array}$} & Good & 126.92 & 24876.00 & \multirow[t]{2}{*}{3054.00} & \multirow[t]{2}{*}{$0.001 *$} \\
\hline & Poor & 91.91 & 4044.00 & & \\
\hline \multirow[t]{2}{*}{ Individual consultations } & Good & 126.32 & 24758.00 & \multirow[t]{2}{*}{3564.00} & \multirow[t]{2}{*}{$0.013^{*}$} \\
\hline & Poor & 100.98 & 4645.00 & & \\
\hline \multirow{2}{*}{$\begin{array}{l}\text { Seminars, training delivered in a } \\
\text { distance mode }\end{array}$} & Good & 127.94 & 25076.00 & \multirow[t]{2}{*}{3246.00} & \multirow[t]{2}{*}{$0.002 *$} \\
\hline & Poor & 94.07 & 4327.00 & & \\
\hline \multirow{2}{*}{$\begin{array}{l}\text { Consultations delivered in a } \\
\text { distance mode }\end{array}$} & Good & 125.78 & 24652.00 & \multirow[t]{2}{*}{3670} & \multirow[t]{2}{*}{$0.04 *$} \\
\hline & Poor & 103.28 & 4751.00 & & \\
\hline \multirow{2}{*}{$\begin{array}{l}\text { Presentation of useful information } \\
\text { in specialised Internet portals }\end{array}$} & Good & 125.26 & 24550.00 & \multirow[t]{2}{*}{3772.00} & \multirow[t]{2}{*}{$0.05^{*}$} \\
\hline & Poor & 105.50 & 4853.00 & & \\
\hline \multirow[t]{2}{*}{ Instructional films on TV } & Good & 121.92 & 23896.00 & \multirow[t]{2}{*}{4426.00} & \multirow[t]{2}{*}{0.84} \\
\hline & Poor & 119.72 & 5507.00 & & \\
\hline \multirow{2}{*}{$\begin{array}{l}\text { Announcement of information on } \\
\text { courses via regional TV }\end{array}$} & Good & 120.52 & 23622.00 & \multirow[t]{2}{*}{4316.00} & \multirow[t]{2}{*}{0.64} \\
\hline & Poor & 125.67 & 5781.00 & & \\
\hline \multirow{2}{*}{$\begin{array}{l}\text { Announcement of information on } \\
\text { courses via mobile telephones }\end{array}$} & Good & 126.17 & 24730.00 & \multirow[t]{2}{*}{3592.00} & \multirow[t]{2}{*}{$0.03 *$} \\
\hline & Poor & 101.59 & 4673.00 & & \\
\hline \multirow{2}{*}{$\begin{array}{l}\text { Announcement of information on } \\
\text { courses via e-mail }\end{array}$} & Good & 125.22 & 24544.00 & \multirow[t]{2}{*}{3778.00} & \multirow[t]{2}{*}{0.07} \\
\hline & Poor & 105.63 & 4859.00 & & \\
\hline
\end{tabular}

* Statistically significant difference

Table 7

Experience of the surveyed in distance learning: the place of learning

\begin{tabular}{lrr}
\hline Statements & N & $\%$ \\
\hline Learning in a distance mode at an institution of higher education & 70 & 33.7 \\
Learning in a distance mode at the work place & 18 & 8.7 \\
Learning in a distance mode at a comprehensive school & 4 & 1.9 \\
\hline
\end{tabular}

adult education displays the need for distance learning services (Vilkonis, Turskiené, 2009).

The analysis of the experience in distance learning in the aspect of application of e-learning technologies shows that still the reading of a text and control, assessment of learning outcomes dominate (Table 8). Many of the surveyed have gained experience in collaboration and participation in discussions, a small part has experience in participation in video conferences. 
Table 8

Experience of the surveyed in distance learning: modes of learning

\begin{tabular}{lll}
\hline Statements & $\mathrm{N}$ & $\%$ \\
\hline Tests carried out in a distance mode within e-learning environment & 52 & 25.0 \\
Group tasks accomplished in a distance mode within e-learning environment & 44 & 21.2 \\
Texts read in a distance mode within e-learning environment & 40 & 19.2 \\
Discussions held in a distance mode within e-learning environment & 30 & 14.4 \\
Learning in a mode of videoconferencing & 16 & 7.7 \\
\hline
\end{tabular}

Results of the comparative analysis are presented in Table 9. It aimed at estimating whether attitudes of the respondents were impacted by the experience gained in the field of distance learning.

A comparative analysis of the results shows that those who have gained experience in distance learning are more willing to choose the modes of distance learning. This shows that the experience gained is assessed positively. It was noticed that those who have experience in distance learning highly evaluate individual consultations. There is no statisti-

Table 9

Analysis of the choice of educational-information support in the context of distance learning experience

\begin{tabular}{|c|c|c|c|c|c|}
\hline & $\begin{array}{l}\text { Experience } \\
\text { in distance } \\
\text { learning }\end{array}$ & $\begin{array}{l}\text { Mean } \\
\text { Rank }\end{array}$ & $\begin{array}{l}\text { Sum of } \\
\text { Ranks }\end{array}$ & $\begin{array}{l}\text { Mann - } \\
\text { Whitney } \\
\text { U }\end{array}$ & $\mathrm{p}$ \\
\hline \multirow[t]{2}{*}{ Theoretical lectures in auditoria } & Yes & 122.38 & 12238.00 & \multirow[t]{2}{*}{6412.00} & \multirow[t]{2}{*}{0.43} \\
\hline & No & 115.65 & 15728.00 & & \\
\hline \multirow{2}{*}{$\begin{array}{l}\text { Blend of lectures and practical classes in } \\
\text { auditoria }\end{array}$} & Yes & 124.42 & 12442.00 & \multirow[t]{2}{*}{6208.00} & \multirow[t]{2}{*}{0.22} \\
\hline & No & 114.15 & 15524.00 & & \\
\hline \multirow[t]{2}{*}{ Individual consultations } & Yes & 130.79 & 13341.00 & \multirow[t]{2}{*}{5784.00} & \multirow[t]{2}{*}{$0.01 *$} \\
\hline & No & 111.03 & 15100.00 & & \\
\hline \multirow[t]{2}{*}{ Seminars, training delivered in a distance mode } & Yes & 132.44 & 13509.00 & \multirow[t]{2}{*}{5616.00} & \multirow[t]{2}{*}{$0.01 *$} \\
\hline & No & 109.79 & 14932.00 & & \\
\hline \multirow[t]{2}{*}{ Consultations delivered in a distance mode } & Yes & 132.99 & 13565.00 & \multirow[t]{2}{*}{5560.00} & \multirow[t]{2}{*}{$0.01 *$} \\
\hline & No & 109.38 & 14876.00 & & \\
\hline \multirow{2}{*}{$\begin{array}{l}\text { Presentation of useful information in } \\
\text { specialised Internet portals }\end{array}$} & Yes & 126.44 & 12897.00 & \multirow[t]{2}{*}{6228.00} & \multirow[t]{2}{*}{0.13} \\
\hline & No & 114.29 & 15544.00 & & \\
\hline \multirow[t]{2}{*}{ Instructional films on TV } & Yes & 126.25 & 12877.00 & \multirow[t]{2}{*}{6248.00} & \multirow[t]{2}{*}{0.16} \\
\hline & No & 114.44 & 15564.00 & & \\
\hline \multirow{2}{*}{$\begin{array}{l}\text { Announcement of information on courses via } \\
\text { regional TV }\end{array}$} & Yes & 135.26 & 13797.00 & \multirow[t]{2}{*}{5328.00} & \multirow[t]{2}{*}{$0.001 *$} \\
\hline & No & 107.68 & 14644.00 & & \\
\hline \multirow{2}{*}{$\begin{array}{l}\text { Announcement of information on courses via } \\
\text { mobile telephones }\end{array}$} & Yes & 130.42 & 13303.00 & \multirow[t]{2}{*}{5822.00} & \multirow[t]{2}{*}{$0.03 *$} \\
\hline & No & 111.31 & 15138.00 & & \\
\hline \multirow{2}{*}{$\begin{array}{l}\text { Announcement of information on courses via } \\
\text { e-mail }\end{array}$} & Yes & 122.79 & 12525.00 & \multirow[t]{2}{*}{6600.00} & \multirow[t]{2}{*}{0.49} \\
\hline & No & 117.03 & 15916.00 & & \\
\hline
\end{tabular}


cally significant difference between those who have and have not gained experience in distance learning when choosing presentation of information on the Internet for reading because such experience has been also gained by those who are inexperienced in learning in a distance mode. Some prognoses can be drawn that application of e-learning technologies spreading in the system of comprehensive education and higher education will make face-to-face and distance learning closer, will make impact in the future on adults' attitudes towards distance learning.

\section{Conclusions}

1. On the ground of good self-assessment in computer literacy, the ability to use ICT at work, at home and social milieu as well as the frequency of usage, usage of eservices and preconceived attitude towards the choice of educational-information support based on e-learning technologies expressed by majority of the surveyed, it can be stated that majority of adults are ready to participate in the process of lifelong learning using distance e-learning, m-learning and t-learning technologies.

2. The possibilities and demand of adults to use e-learning and m-learning technologies can change depending on the ability to use ICT and experience of using of eservices, but there is no relations between learners' ability to use ICT and attitudes towards t-learning.

3. Readiness of adults to learn using e-learning, m-learning and t-learning technologies is prompted by good computer literacy, by experience gained in the field of distance learning and other e-services.

\section{References}

Aarreniemi-Jokipelto, P. (2005). T-learning model for learning via digital TV. In: $16^{\text {th }}$ EAEEIE Annual Conference on Innovation in Education for Electrical and Information Engineering. Lappeenranta, Finland.

Bitinas, B. (2006). Edukologinis tyrimas: sistema ir procesas. Vilnius: Kronta.

Butkevičienè, E., Rutkauskienė, D., Daukilas, S., Gudonienė, D., Mušankovienė, V.R. (2008). E. mokymosi ypatybių švietimo sektoriuose studija. Kaunas.

Čekanavičius, V., Murauskas, G. (2000). Statistika ir jos taikymai. Vilnius: TEV.

Kapenieks, A., Bruno, Z., Ginta, S., Jirgensons, M. (2012). An e-ecosystem driven next generation life long learning approach. In: Cunningham, P., Cunningam, M. (Eds.), IST-Africa 2012 Conference Proceedings. IIMC International Information Management Corporation.

Kardelis, K. (2002). Mokslinių tyrimu metodologija ir metodai. Šiauliai: Liucilijus.

Kazlauskienė, A., Vasiliauskienė, E., Gaučaitė, R., Pocevičienė, R. (2010). Savivaldaus mokymosi organizavimas kaip švietimo inovacija: Bolonijos proceso kontekstas. Mokytojų ugdymas, 15 (2). 93-111.

Misevičienė, R., Budnikas, G., Ambrazienè, D. (2011). Application of cloud computing at KTU: ms live@edu case. Informatics in Education, 10(2). 259-270.

Nuotolinis mokymasis (2003). Comp. by D. Rutkauskienè. Kaunas: Technologija.

Šileikienè, I. (2004). Kompiuterinés mokymo sistemos [accessed on 1 July 2009]. Accessed via the Internet at: http://gama.vtu.1t/KMS/KMS_teorija.doc

Targamadzè, A., Petrauskienè, R. (2010). Impact of information technologies on modern learning. Information Technology and Control, 39 (3). 169-175.

Teresevičienė, M., Rutkauskienė, D., Volungevičienė, A., Zuzevičiūtė, V., Rutkienė, A., Targamadzė, A. (2008). Nuotolinio mokymo(si) taikymo galimybès tęstinio profesinio mokymo pletrai skatinti. Kaunas: Vytauto Didžiojo universiteto leidykla. 
Vaičiūnienė, V., Gedvilienė, G. (2008). Studentų mokymosi patirtis taikant integruotą informacinio raštingumo kursą virtualioje mokymosi aplinkoje. Informatics in Education, 7(1). 127-142.

Valiuškevičiūtè, A. (2005). Nuotolinis mokymas kaip atvirojo mokymosi idejos realizacija švietimo organizacijoje: universitetinè patirtis. Nuotolinés studijos Lietuvos kolegijose: aktualijos ir perspektyvos (conference presentation). Kaunas.

Vilkonis, R., Turskienè, S. (2009). Nuotolinio mokymosi valdymo specialistų poreikis Lietuvos suaugusiujų neformalaus švietimo centruose. Mokslas ir socialiniai procesai, 3(19). 178-186.

Vilkonis, R., Barabanova, I. (2010). Vidurinès mokyklos mokinių savarankiško mokymosi patirties analizė nuotolinio ir elektroninio mokymo(si) kontekste. Mokytojų ugdymas, 14(1), 121-136.

Wedemeyer, Ch.A. (1973). The "open” school: education's runnemede? Educational Technology, 12 (1). 65-68.

Wishart J. (2009). Use of mobile technology for teacher training. Mobile Learning: Transforming the Delivery of Education and Training. Accessed via the Internet at: www . aupress . ca/ index . php/books/120155 (accessed on 15 September 2011).

R. Vilkonis is a Doctor of Social Sciences (Education Studies), Associate Professor of the Department of Education Systems at Faculty of Education of Šiauliai University, senior researcher of the Scientific Centre of Research in Education, senior researcher of Distance Studies Centre.

S. Turskienè is a Doctor of Technology, director of Distance Studies Centre of Šiauliai University, Associate Professor of the Department of Informatics.

T. Bakanovienė is a Doctor of Social Sciences (Education Studies), lecturer of the Department of Education Systems at Faculty of Education of Šauliai University, researcher of the Scientific Centre of Research in Education.

\title{
Suaugusiųjų pasirengimas mokytis naudojant ịvairias nuotolinio mokymosi technologijas
}

\author{
Rytis VILKONIS, Tatjana BAKANOVIENÉ, Sigita TURSKIENE்
}

Straipsnyje pristatomi empirinio tyrimo apie suaugusiujų pasirengimą dalyvauti visą gyvenimą trunkančiame mokymosi procese, naudojantis elektroninio mokymosi, mobiliojo mokymosi ir televizinio mokymosi technologijomis, rezultatai. Tyrimas buvo atliktas vykdant tarptautinio projekto „eBig3“ veiklas, kuriomis buvo siekiama sukurti naują nuotolinio mokymosi platformą, susiejančią virtualiąsias mokymosi aplinkas, televizijos ir mobiliąsias technologijas. Pasirengimas mokytis nuotoliniu būdu naudojant tris technologijas buvo analizuojamas vertinant suaugusiujų kompiuterinio raštingumo gebèjimus, el. paslaugų naudojimą el. mokymosi kontekste, turimą patirtị ir nuostatas mokymosi būdų pasirinkimo atžvilgiu. 